\title{
GAMBARAN PUTUS BEROBAT DARI SUDUT PANDANG PENDERITA DAN PENGAWAS MINUM OBAT DI KOTAMADYA PAREPARE
}

\section{Overview Of Drug Withdrawal From Sufferers And Supervisors Of Taking Medicine Viewpoint In Parepare}

\author{
I Wayan Dedus Suriyana', Elly Lilianty Sjattar ${ }^{2}$, Andi Masyitha Irwan ${ }^{3}$, Hapsah $^{4}$ \\ ${ }^{1}$ Mahasiswa Program Studi Magister Ilmu Keperawatan, Universitas Hasanuddin Makassar \\ ${ }^{2,3,4}$ Dosen Program Studi Magister Ilmu Keperawatan, Universitas Hasanuddin Makassar \\ e-mail: iwayan.dedus73@gmail.com
}

\begin{abstract}
ABSTRAK
Latar Belakang : Tuberkulosis paru adalah penyakit infeksi dan kuman penyebabnya telah diketahui serta obat-obatan untuk menyembuhkan sudah sangat efektif dan maju pesat, namun masalah pemberantasan dan penanggulangannya sampai saat ini belum memuaskan, sehingga perlu uraian tentang gambaran putus obat penderita tuberkulosis ditinjau dari penderita dan pengawas minum obat.

Tujuan : Memberikan gambaran putus berobat dari sudut pandang penderita tuberkulosis dan pengawas minum obat di Puskesmas dalam wilayah kerja Dinas Kesehatan Kotamadya Parepare.

Metode : Penelitian deskriptif ini memiliki 32 responden 16 orang penderita tuberkulosis paru, dan 16 orang pengawas minum obat, yang diperoleh secara purposive sampling. Data ditelusuri dengan wawancara terstruktur dengan mempertimbangkan peran masing-masing responden.

Hasil : Penelitian ini menunjukkan bahwa penderita mengalami putus obat (12 laki-laki; 4 perempuan; ratarata berusia 47,81 tahun (21-71tahun)); dengan rata-rata lama terdiagnosis tuberkulosis 6,94 bulan $( \pm 3,1$; range: $3-13$ bulan) dan rata-rata lama konsumsi obat anti tuberkulosis 1,95 bulan ( $\pm 1,2$; range: $1-4$ bulan). Pengawas minum obat berjumlah 16 orang yang terdiri dari laki-laki 2 orang $(12,5 \%)$, dan perempuan sebanyak 14 orang $(87,5 \%)$. Penderita tuberkulosis memiliki pengawas minum obat sebanyak 16 orang (100\%). Pengawan minum obat dan keluarga mendukung pengobatan pasien sebanyak 13 orang $(81,25 \%)$. Alasan putus berobat ada dua yaitu yang pertama karena efek samping obat seperti Mual, muntah, Pusing, nyeri sendi, badan tertusuk-tusuk sebanyak 12 orang (75\%) dan alasan yang kedua adalah penderita tuberkulosis merasa sembuh sebanyak 4 orang $(25 \%)$.

Kesimpulan : Mayoritas penderita tuberkulosis mengalami putus obat disebabkan karena efek samping obat sehingga menurunkan keinginan untuk melanjutkan pengobatan meskipun memperoleh dukungan dari keluarga dan petugas kesehatan.
\end{abstract}

Kata kunci : Penderita tuberkulosis, Pengawas minum obat, Putus Berobat.

\section{ABSTRACT}

Background: Pulmonary tuberculosis is an infectious disease, the germs that cause it are known and the drugs to cure are very effective and rapidly progress, but the problem of eradicating and overcoming nowadays has not been satisfactory, so it is necessary to describe the overview of drug withdrawal of tuberculosis sufferers in terms of sufferers and supervisors of taking medication.

Objective: To provide an overview of drug withdrawal from the viewpoint of the tuberculosis sufferers and the supervisors of taking medication at Public health center in the work area of Municipality Health Office of Parepare.

Methods: This descriptive study had 32 respondents 16 people with pulmonary tuberculosis, and 16 supervisors of taking medication, which was obtained by purposive sampling. Data was traced by structured interviews by considering the role of each respondent.

Results: This study showed that the sufferers experienced drug withdrawal (12 males; 4 females; mean of age 47.81 years-old (21-71 years); with the average duration of tuberculosis diagnosed was 6.94 months ( \pm 3.1; range:3-13 months) and the average length of consumption of anti-tuberculosis drugs was 1.95 months ( \pm 1.2 ; range: $1-4$ months) Supervisors of taking medicine as many as 16 people consisting of 2 male (12, $5 \%)$, and 14 female (87.5\%). Tuberculosis sufferers who have supervisor of taking medication were 16 people (100\%). Supervisors of taking medicine and family support the treatment of sufferers as many as 13 people (81.25\%). There were two reason of drug withdrawal, the first due to side effects of drugs such as nausea, vomiting, dizziness, joint pain, stabbing of the body, many as 12 people (75\%) and the second reason was the tuberculosis sufferers felt healed 4 people $(25 \%)$

Conclusions: The majority of tuberculosis sufferers experienced drug withdrawal due to side effects of the drug thus decreasing desire to continue treatment despite getting support from family and health workers.

Key words : Tuberculosis sufferers, supervisors of taking medication, drug withdrawal. 


\section{PENDAHULUAN}

Tuberkulosis (TB) adalah penyakit infeksi yang menular disebabkan oleh basil mycobacterium tuberkulosis. Sebagian besar basil mycobacterium TB menyerang paru (TB paru), tetapi dapat juga menyerang organ tubuh yang lain (TB extra paru), seperti tulang, kelenjar limfe, pleura, dan lain-lain (Breu et al, 2008 ; Tjokroprawiro et al., 2015).

Mycobacterium TB adalah penyebab $\mathrm{TB}$ dan sangat pathogen terhadap manusia. Secara umum basil mycobacterium TB adalah berbentuk batang dengan panjang 1-10 mikron, lebar 0,2-0,6 mikron, tahan asam, berwarna merah, tahan terhadap suhu $4^{\circ} \mathrm{C}$ sampai minus $7^{\circ} \mathrm{C}$, kuman sangat peka terhadap sinar matahari dan sinar ultraviolet, dan kuman akan mati pada suhu $30^{\circ} \mathrm{C}-37^{\circ} \mathrm{C}$ dalam waktu kurang dari 1 minggu. Dinding basil TB tertutup lemak sehingga kuman ini tahan terhadap asam (asam alkohol) disebut Basil Tahan Asam (BTA), basil mycobacterium TB tahan terhadap gangguan kimia. Basil mycobacterium TB pada saat dormant dapat hidup di udara yang kering maupun udara yang yang dingin, atau dapat hidup bertahun-tahun dalam lemari es (Tjokroprawiro et al., 2015).

Penyakit TB merupakan penyakit yang cukup besar jumlahnya di dunia. Prevalensi TB paru di dunia pada tahun 2016 sebanyak 6,3 juta kasus atau naik dari 6,1 juta pada tahun 2015 (World Health Organization, 2017). Di Indonesia TB paru pada tahun 2016 sebanyak 351.893 kasus, meningkat dibandingkan tahun 2015 sebanyak 330.729 kasus. Namun keberhasilan pengobatan menurun yaitu: tahun 2014 sebanyak 90,1\%, tahun 2015 sebanyak 84\%. Dengan menurunnya tingkat keberhasilan pengobatan TB paru berimplikasi pada angka kematian akibat TB paru meningkat, serta menghambat tercapainya target kesehatan nasional (Hardhana et al., 2017; World Health Organization, 2017; Kemenkes RI, 2017).

Berbagai upaya pengendalian telah dilakukan untuk menurunkan angka insiden dan kematian akibat TB paru, namun diperkirakan antara tahun 2000-2020 kematian akibat TB hampir 35 juta orang, namun data putus berobat di Indonesia maupun dunia tidak diketahui (World Health Organization, 2016; Mohammadzadeh, Ghyoomi, \& Maghsoudloo, 2016).
Data dari Dinas Kesehatan Kotamadya Parepare mengambarkan kejadian kejadian TB paru pada tahun 2015 sebanyak 341 kasus, sedangkan pada tahun 2016 menurun sebanyak 293 kasus. Angka kesembuhan penderita TB paru BTA+ di wilayah kerja dinas kesehatan Kotamadya Parepare pada tahun 2015 sebanyak 68\%, sementara angka putus berobat (drop out) sebanyak 3,5\%, dan pada tahun 2016 angka keberhasilan pengobatan sebanyak $82 \%$, sementara angka putus berobat (drop out) meningkat menjadi 5,9\%. Angka keberhasilan pengobatan tidak mencapai target yang ditetapkan organisasi kesehatan dunia (WHO) yang menargetkan 85,0\% (WHO, 2016; Dinkes Sulsel, 2016).

Meski TB paru adalah penyakit infeksi dan kuman penyebabnya sudah diketahui serta obat-obatan untuk menyembuhkan sudah sangat efektif dan maju pesat, namun masalah pemberantasan dan penanggulangannya sampai saat ini belum memuaskan. Beberapa akibat yang dapat terjadi jika pemberantasan dan penanggulangan TB paru tidak memuaskan antara lain meningkatnya kasus TB paru karena rantai penularan TB paru tidak bisa di putuskan, meningkatnya resistensi obat TB atau Multidrug Resistance (MDR), yang pada akhirnya akan menyebabkan epidemi TB yang sulit di tangani (Kemenkes RI, 2014; World Health Organization, 2016; Sjattar, Nurrahmah, Bahar, 2011).

Di Indonesia, pengobatan dan perawatan TB paru dilakukan oleh petugas yang terlibat dalam penanggulangan TB paru dengan strategi Directly Observed Treatment Shortcourse (DOTS) antara lain: Dokter umum menetapkan diagnosa TB, petugas laboratorium sebagai pemerikasa sputum, keluarga atau petugas kesehatan sebagai PMO, perawat sebagai pelaksana program TB Puskesmas, dan Kepala Puskesmas sebagai penanggung jawab program TB Puskesmas (Kemenkes RI, 2016; Tjokroprawiro, Setiawan, Effendi, 2015).

Tingkat keberhasilan pengobatan TB paru sangat ditentukan oleh keteraturan minum Obat Anti TB (OAT). Keteraturan minum obat dapat dicapai dengan adanya PMO, yang mengawasi dan megingatkan penderita TB paru untuk minum obat secara teratur. Disamping itu pengawasan dan edukasi yang baik dari pelaksana program TB di Puskesmas dan Wasor TB Kabupaten dapat 
meningkatkan keberhasilan pengobatan Dengan keterlibatan semua pihak, diharapkan penderita TB termotivasi untuk melakukan pengobatan secara teratur sampai dinyatakan sembuh (Tjokroprawiro et al. 2015; Sukoco 2012).

\section{METODE}

\section{Jenis Penelitian}

Jenis penelitian yang digunakan adalah deskriptif study. Lokasi penelitian adalah semua Puskesmas dalam wilayah kerja Dinas Kesehatan Kotamadya Parepare Sulawesi Selatan yakni sebanyak 6 Puskesmas.

\section{Populasi dan Sampel}

Populasi adalah penderita TB paru yang putus berobat dan pengawas Minum Obat (PMO) di Puskesmas dalam wilayah kerja Dinas Kesehatan Kotamadya Parepare yang tercatat sebagai penderita TB dan PMO di masing-masing Puskesmas. Sampel penelitian ini adalah penderita TB paru yang putus berobat sebanyak 16 orang dan PMO sebanyak 16 orang, jadi jumlah keseluruhan responden adalah 32 orang.

\section{Lokasi dan Waktu Penelitian}

Penelitian ini berlokasi di Puskesmas dalam wilayah kerja Dinas Kesehatan Kotamadya Parepare. Penelitian dilaksanakan pada tanggal 25 Mei-27 Juni 2018.

\section{Teknik Pengambilan sampel}

Teknik pengambilan sampel dengan purporsive sampling dengan kriteria inklusi adalah responden penderita TB paru yang putus berobat selama 2 bulan terus menerusmenerus atau lebih yang dibuktikan dengan rekam medik (TB-01), anggota keluarga atau petugas kesehatan sebagai PMO. Sedangkan kriteria eksklusi adalah tidak berada di tempat dan penderita TB dengan komplikasi penyakit kronis seperti HIV/AIDS, Diabetes Mellitus, penyakit hati akut atau kronik.

\section{Pengumpulan Data}

Instrumen yang digunakan pada penelitian ini adalah pedoman wawancara dan studi dekumen.

\section{Pengumpulan dan Analisa Data \\ Analisa data dilakukan dengan analisis deskriptif secara tendency central dan}

distribusi frekwensi. Penelitian ini telah mendapat persetujuan dari komisi etik penelitian kesehatan Fakultas Kedokteran Universitas Hasanuddin Nomor: 353/H4.8.4.5.31/PP36-KOMETIK/2017 tanggal : 9 Mei 2018.

\section{HASIL}

Penelitian ini menunjukkan bahwa presentase penderita TB paru yang mengalami putus obat (12 laki-laki; 4 perempuan; ratarata berusia 47,81 tahun (21-71 tahun); dengan rata-rata lama terdiagnosis TB 6,94 bulan ( $\pm 3,1$; range $3-13$ bulan) dan rata-rata lama konsumsi obat TB 1,95 bulan $( \pm 1,2$; range: $1-4$ bulan).

Pada penelitian ini persepsi penderita TB tentang ketersediaan obat di Puskesmas sebanyak 16 orang (100\%), niat untuk berobat lanjut sebanyak 10 orang $(62,5 \%)$, dukungan keluarga pada penderita TB paru untuk berobat sebanyak 13 orang $(81,25 \%)$, Alasan utama putus obat adalah mengalami efek samping Obat Anti Tuberkulosis (OAT) sebanyak 12 orang $(75 \%)$ sedangkan sisanya sebanyak 4 orang $(25 \%)$ adalah merasa sudah

Tabel 1. Data Demografi Responden penderita TB paru $(n=16)$

\begin{tabular}{lccc}
\hline \multicolumn{1}{c}{ Karateristik } & n & $\%$ & $\begin{array}{c}\text { Mean } \\
\text { (min-max) }\end{array}$ \\
\hline Pasien TB paru & & & \\
\hline $\begin{array}{c}\text { Jenis Kelamin } \\
\text { Laki-Laki } \\
\text { perempuan }\end{array}$ & 12 & 75 & \\
\multicolumn{1}{c}{ Pendidikan } & 25 & \\
$\quad$ SD & 5 & 31,2 & \\
$\quad$ SMP & 8 & 50,0 & \\
$\quad$ SMA & 3 & 18,8 & \\
\hline Usia & & & $47,81(21-71)$ \\
\hline $\begin{array}{l}\text { Lama terdiagnosa } \\
\text { TB }\end{array}$ & & $6,94(3-13)$ \\
\hline $\begin{array}{l}\text { Lama komsumsi } \\
\text { obat }\end{array}$ & & $1,95(1-4)$ \\
\hline
\end{tabular}

Presentase PMO di Puskesmas dalam wilayah kerja Dinas Kesehatan Kotamadya Parepare yang terbesar dengan jenis kelamin perempuan sebanyak 14 orang $(87,5 \%)$, tingkat pendidikan PMO terbanyak adalah Sekolah Dasar (SD) sebanyak 6 orang (37,4\%), selebihnya adalah Sekolah Menengah Pertama (SMP) dan Sekolah Menengah Atas (SMA) masing-masing 
sebanyak sebanyak 5 orang $(31,3 \%)$. Usia PMO rata-rata berumur 41,94 (26-56) tahun, dengan pekerjaan sebagian besar adalah Urusan Rumah Tangga (URT) sebanyak 9 orang $(56,3 \%)$, Wiraswasta sebanyak 5 orang $(31,2 \%)$ dan Pegawai Negeri Sipil (PNS) sebanyak 2 orang $(12,5 \%)$.

Tabel 2. Data demografi responden pengawas minum obat (PMO) $(\mathrm{n}=16)$

\begin{tabular}{lccc}
\hline Karateristik & n & $\%$ & $\begin{array}{c}\text { Mean } \\
(\mathbf{m i n}-\mathbf{m a x})\end{array}$ \\
\hline Pengawas Minum Obat (PMO) & \\
\hline Jenis Kelamin & & & \\
$\quad$ Laki-Laki & 2 & 12,5 & \\
$\quad$ perempuan & 14 & 87,5 & \\
\hline Pendidikan & & & \\
$\quad$ SD & 6 & 37,4 & \\
SMP & 5 & 31,3 & \\
$\quad$ SMA & 5 & 31,3 & \\
\hline Usia & & & $41,94(26-56)$ \\
\hline Pekerjaan PMO & & & \\
$\quad$ Wiraswasta & 5 & 31,3 & \\
$\quad$ URT & 9 & 56,3 & \\
$\quad$ Pegawai & & & \\
$\quad$ Negeri Sipil & 2 & 12,5 & \\
& & &
\end{tabular}

Pada penelitian ini persepsi PMO terhadap pengelolaan TB paru di Puskesmas dalam wilayah kerja Dinas Kesehatan Kotamadya parepare adalah motivasi penderita untuk berobat sangat rendah sebanyak 7 orang $(43,75)$, Semua PMO tidak dilatih, sebanyak 16 orang (100\%), Pemilihan PMO sebagian besar tinggal serumah, penyuluhan pada penderita TB paru untuk berobat masih rendah sebanyak 7 orang $(43,75 \%)$. Sebagian besar keluarg mendukung penderita TB paru untuk berobat sebanyak $81,25 \%$, dan peran PMO mengawasi penderita TB paru menelan obat sebanyak 16 orang $(100 \%)$, mendorong penderita TB paru agar mau berobat teratur sebanyak 7 orang $(43,75 \%)$, PMO tidak mengigatkan untuk periksa ulang dahak dan tidak memberikan penyuluhan kepada keluarga penderita TB masing-masing sebanyak 16 orang $(100 \%)$.

Penderita TB paru pada tahun 2015 di Kotamadya Parepare sebanyak 341 orang, angka keberhasilan pengobatan sebanyak $68 \%$, sementara angka putus berobat (drop out) sebanyak 3,5\%, dan pada tahun 2016 jumlah penderita 293 orang, angka keberhasilan pengobatan sebanyak $82 \%$, sementara angka putus berobat (drop out) meningkat menjadi 5,9\% (Dinkes Sulsel, 2015; Dinkes Sulsel, 2016).

Tabel 3. Gambaran penderita TB paru yang putus berobat terhadap pengelolaan TB di Puskesmas dalam wilayah kerja Dinas

Kesehatan Kotamadya Parepare $(\mathrm{n}=16)$.

\begin{tabular}{|c|c|c|c|c|c|}
\hline \multirow{2}{*}{$\begin{array}{l}\mathbf{N} \\
\mathbf{o}\end{array}$} & \multirow{2}{*}{ Keterangan } & \multicolumn{2}{|c|}{ Ya } & \multicolumn{2}{|c|}{ Tidak } \\
\hline & & $\mathbf{n}$ & $\%$ & n & $\%$ \\
\hline 1 & $\begin{array}{r}\text { Tersedianya } \\
\text { obat di PKM }\end{array}$ & 16 & 100 & 0 & 0 \\
\hline \multirow[t]{2}{*}{2} & $\begin{array}{l}\text { Lamanya } \\
\text { berobat TB } \\
\text { - > } 2 \text { bulan }\end{array}$ & 9 & 56,25 & 0 & 0 \\
\hline & - $<2$ bulan & 7 & 43,75 & 0 & 0 \\
\hline \multirow[t]{3}{*}{3} & $\begin{array}{l}\text { Lamanya } \\
\text { Menderita }\end{array}$ & & & & 0 \\
\hline & $\begin{array}{l}\mathrm{TB} \\
\text { - }>6 \text { bulan }\end{array}$ & 5 & 31,25 & 0 & 0 \\
\hline & - $<6$ bulan & 11 & 68,75 & 0 & 0 \\
\hline \multirow[t]{2}{*}{4} & $\begin{array}{l}\text { Alasan Putus } \\
\text { Obat } \\
\text { - Karena } \\
\text { Merasa } \\
\text { sembuh }\end{array}$ & 12 & 75 & 0 & 0 \\
\hline & $\begin{array}{l}\text { Efek } \\
\text { samping } \\
\text { obat }\end{array}$ & 4 & 25 & 0 & 0 \\
\hline 5 & $\begin{array}{l}\text { Memperoleh } \\
\text { Dukungan } \\
\text { Keluarga } \\
\end{array}$ & 13 & 81,25 & 3 & 18,75 \\
\hline 6 & $\begin{array}{l}\text { Mempunyai } \\
\text { Pengetahuan } \\
\text { tentang } \\
\text { Penyakit TB } \\
\text { paru }\end{array}$ & 10 & 62,5 & 6 & 37,5 \\
\hline 7 & $\begin{array}{l}\text { Kunjungan } \\
\text { petugas } \\
\text { kesehatan ke } \\
\text { rumah } \\
\text { pasien }\end{array}$ & 16 & 100 & 0 & 0 \\
\hline 8 & $\begin{array}{l}\text { Niat Lanjut } \\
\text { berobat }\end{array}$ & 10 & 62,5 & 6 & 37,5 \\
\hline
\end{tabular}


Tabel 4. Alasan Putus Obat Penderita TB paru di Puskesmas Dalam Wilayah Kerja DinasKesehatan Kotamadya Parepare Tahun 2018 (n=16).

\begin{tabular}{lcc}
\hline \multicolumn{1}{c}{ Alasan Putus Berobat Pada Penderita TB } & n & \% \\
\hline Efek Samping Obat & & 25 \\
\hline Mual & 4 & 18,75 \\
\hline Muntah & 3 & 6,25 \\
\hline Pusing & 1 & 6,25 \\
\hline Nyeri sendi & 1 & 6,25 \\
\hline Tertusuk seluruh badan & 1 & 6,25 \\
\hline Nyeri dada, sesak & 1 & 6,25 \\
\hline Gemetar & 1 & 25 \\
\hline Merasa sembuh & 4 & $\mathbf{1 0 0}$ \\
\hline Total & $\mathbf{1 6}$ &
\end{tabular}

\section{PEMBAHASAN}

Berdasarkan hasil penelitian di Puskesmas dalam wilayah kerja Dinas Kesehatan Kotamadya Parepare menunjukkan bahwa prosentase jenis kelamin responden menunjukkan bahwa penderita TB laki-laki sebanyak 12 orang $(75 \%)$, dibandingkan dengan penderita wanita sebanyak 4 orang (25\%). Penelitian ini sejalan dengan penelitian yang dilakukan (Horton, MacPherson, Houben, White, 2016; Jumbo, Obaseki, \& Ikuabe, 2013). Menjelaskan bahwa jumlah penderita TB paru 2625 , prevalensi penderita laki-laki lebih tinggi dari pada perempuan yaitu 1612 vs 1013 dengan OR 1,59.

Hasil penelitian ini menunjukkan Penderita TB paru berusia rata-rata 47,81 tahun (21-71 tahun), penelitian ini sejalan dengan Penelitian yang dilakukan oleh ( $\mathrm{Li}$, Ge, Shen 2016; Syed, 2014) menjelaskan kegagalan pengobatan berusia rata-rata diatas 44 tahun, motivasi untuk berobat yang kurang dan efek samping yang dialami umumnya lebih berat sehingga angka putus berobat meningkat.

Opini peneliti bahwa semakin tua penderita motivasi untuk berobat semakin rendah yang di pengaruhi oleh daya tahan tubuh yang lemah dan efek samping obat yang dirasakan juga lebih berat, penelitian ini sejalan dengan penelitian yang dilakukan oleh (Octovianus, Suhartono, \& Kuntjoro, 2015), diketahui golongan umur lebih dari 45 tahun lebih banyak mengalami putus berobat $(63,2 \%)$ dibanding golongan umur kurang dari 45 tahun $(46,9 \%)$ hal ini terkait dengan motivasi untuk berobat yang kurang dan efek samping yang dialami umumnya lebih berat.

Hasil penelitian ini menunjukkan ratarata lama terdiagnosis TB 6,94 bulan $( \pm 3,1$; range: $3-13$ bulan) dan rata-rata lama konsumsi obat TB 1,95 bulan $( \pm 1,2$; range: $1-$ 4 bulan), dimana pasien putus berobat dalam tahap pengobatan intensif. Penelitian ini sejalan dengan penelitian yang dilakukan oleh (Mardhiyyah \& Carolia, 2016; Kimberly, Szechuan, \& Jeremy, 2014) menjelaskan bahwa setelah pasien melakukan pengobatan tahap intensif, biasanya pasien menganggap dirinya sembuh dan menghentikan pengobatannya.

Pada penelitian ini alasan utama putus obat adalah mengalami efek samping obat sebanyak 12 orang $(75 \%)$ sedangkan sisanya sebanyak 4 orang $(25 \%)$ merasa sembuh dan tidak membutuhkan pengobatan lagi. Penelitian ini sejalan dengan penelitian yang dilakukan oleh (Deshmukh, Dhande, \& Sachdeva, 2015;Dewanty et al., 2015) dimana efek samping obat merupakan masalah yang menjadi penyebab putus berobat pada penderita TB paru dengan strategi DOTS.

Opini peneliti bahwa penyebab putus obat pada penderita TB paru karena beberapa penderita TB sangat sensitif dengan efek samping OAT dan beberapa penderita TB telah melewati fase intensif sehingga gejala TB berkurang sehingga penderita TB merasa sembuh. Guna mengetahui efek samping OAT, sangat penting dilakukan pemantauan 
kondisi penderita TB selama masa pengobatan, sehingga efek samping berat segera diketahui dan dilakukan tatalaksana yang tepat. Pelaksana TB dapat memantau terjadinya efek samping dengan memberikan edukasi kepada penderita TB untuk mengenal efek samping serta menganjurkan untuk segera melaporkan ke petugas kesehatan bilamana terjadi efek samping dari yang ringan sampai berat. Pada penderita TB yang mengalami efek samping obat yang ringan sebaiknya tetap melanjutkan pengobatan dan diberikan edukasi cara mengatasainya atau diberikan obat tambahan sehingga efek samping berkurang atau hilang (Kementerian Kesehatan RI, 2014).

Pada penelitian ini persepsi PMO terhadap pengelolaan TB paru di Puskesmas dalam wilayah kerja Dinas Kesehatan Kotamadya parepare adalah motivasi penderita untuk berobat sangat rendah yaitu sebanyak 7 orang $(43,75 \%)$. Semua PMO tidak dilatih, sebanyak 16 orang $(100 \%)$, Pemilihan PMO sebagian besar tinggal serumah sebanyak 12 orang (75\%), penyuluhan pada penderita TB paru untuk berobat masih rendah sebanyak 7 orang $(43,75 \%)$. penelitian ini sejalan (Arifin, Muhyi, Setyaningrum, Rahman, \& Marlinae, 2017) yang menjelaskan bahwa keberhasilan pengobatan TB paru sangat ditentukan dengan kinerja PMO, semakin baik kinerja PMO, maka keberhasilan pengobatan akan semakin meningkat. Ada hubungan kinerja PMO dengan keberhasilan pengobatan yaitu $\mathrm{P}=0,013$.

Opini peneliti bahwa PMO semestinya diberikan pelatihan agar memiliki pengetahuan tentang penyakit TB, namun hal ini tidak dilakukan yang berdampak pada meningkatnya angka putus obat pada penderita TB paru di Kotamadya Parepare yaitu tahun 2015 jumlah penderita TB paru sebanyak 341 orang, angka keberhasilan pengobatan sebanyak $68 \%$, sementara angka putus berobat (drop out) sebanyak 3,5\%, dan pada tahun 2016 jumlah penderita 293 orang, angka keberhasilan pengobatan sebanyak $82 \%$, sementara angka putus berobat (drop out) meningkat menjadi 5,9\%. Penelitian ini sejalan dengan penelitian yang dilakukan oleh (Sukoco, 2012; Cytogenetic et al., 2017) bahwa PMO mempunyai peran yang sangat penting dalam menurunkan angka putus obat dan meningkatkan keberhasilan pengobatan, oleh karena itu PMO harus diberikan pelatihan tentang penyakit TB agar kinerjanya baik sehingga keberhasilan pengobatan meningkat serta menurunkan angka putus obat dan PMO adalah orang yang disegani oleh pasien TB.

\section{KESIMPULAN DAN SARAN}

Mayoritas responden (penderita TB) putus berobat karena efek samping obat yang dialami sehingga memungkinkan untuk menurunkan keinginan untuk melanjutkan pengobatan meskipun sudah memperoleh dukungan dari keluarga dan petugas kesehatan.

Peran PMO perlu ditingkatkan melalui upaya pelatihan yang lebih efektif agar penderita TB yang putus berobat menurun dan keberhasilan pengobatan meningkat atau pengobatan TB mencapai target nasional yaitu $85 \%$.

\section{DAFTAR PUSTAKA}

Arifin, S., Muhyi, R., Setyaningrum, R., Rahman, F., \& Marlinae, L. (2017). Development Indicators TB Pulmonary Disease Healing Wetland in the City Banjarmasin (Study of Swallowing Drug Assistance Program Supervisor at Family Core Dots). Airlangga University, Faculty of Public Health, Student of Doctoral Program, and Lambung Mangkurat University, Faculty of Medicine, Departement of Public Health Sciences, Banjarbaru, 8, 15-23.

Cytogenetic, F., Sternopygidae, R., Silva, S., Sua, P., Milhomem, S. S. R., Cabral-demello, D. C., ... Pieczarka, J. C. (2017). Directly Observed Therapy Using Home-Based Supervisors for Training Tuberculosis in Vitoria, Brazil, O(0), 18. https://doi.org/10.1089/zeb.2016.1405

Deshmukh, R. D., Dhande, D. J., \& Sachdeva, K. S. (2015). Patient and Provider Reported Reasons for Lost to Follow Up in MDRTB Treatment: A Qualitative Study from a Drug Resistant TB Centre in India, 1-11. https://doi.org/10.1371/journal.pone.013 5802

Dewanty, L. I., Haryanti, T., Kurniawan, T. P., Masyarakat, F. K., Veteran, U., \& 
Nusantara, B. (2015). Kepatuhan Berobat Penderita TB Paru di Puskesmas Nguntoronadi I Kabupaten Wonogiri, (February), 39-43.

Dinkes Sulsel. (2016). Data Tabel Profil Kesehatan Prov . Sulawesi Selatan Tahun 2016. Retrieved from http://dinkes.sulselprov.go.id/profilkeseh atan-K011.html

Hardhana, B., Budiono, C. S., Kurniasih, N., Manullang, E. V, Susanti, M. I., Pangribowo, S., ... Sigit, B. B. (2017). Profil Kesehatan Indonesia, 2016.

Horton, K. C., MacPherson, P., Houben, R. M. G. J., White, R. G., \& Corbett, E. L. (2016). Sex Differences in Tuberculosis Burden and Notifications in Low- and Middle-Income Countries: A Systematic Review and Meta-analysis. PLOS Medicine, 13(9), e1002119. https://doi.org/10.1371/journal.pmed.100 2119

Jumbo, J., Obaseki, D. O., \& Ikuabe, P. O. (2013). Tuberculosis and Gender parity in a TB Referral Centre, South -South Nigeria. Greener Journal of Medical Sciences, $\quad 3(7), \quad 2276-7797$. https://doi.org/10.15580/GJMS.2013.7.0 82613801

Kemenkes RI. (2014). Infodatin : Pusat Data dan Informasi Kementrian kesehatan RI.

Kemenkes RI. (2016). InfoDatin-2016-TB.

Kementerian kesehatan RI. (2017). Profil Kesehatan Indonesia 2016. Data Dan Informasi.

Kimberly, S. B., Sze-chuan, S., \& Jeremy, D. G.-F. (2014). Tuberculosis Treatment Discontinuation and Symptom Persistence: an Observational Study of Bihar, India's Public Care System Covering > 100,000,000 Inhabitants. BMC Public Health, 14(418), 1-13.

Li, D., Ge, E., Shen, X., \& Wei, X. (2016). Risk Factors of Treatment Outcomes for Multi-drug Resistant Tuberculosis in Shanghai, 2009-2012. Procedia Environmental Sciences, 36, 12-19. https://doi.org/10.1016/j.proenv.2016.09. 003

Mardhiyyah, A., \& Carolia, N. (2016). Multi
Drug Resistant Tuberculosis pada Pasien Drop Out dan Tatalaksana OAT Lini Kedua Multi Drug Resistant Tuberculosis in Patients Drop Out and Management of Second Line Anti Tuberculosis, 5(April), 11-16.

Mohammadzadeh, K. A., Ghayoomi, A., \& Maghsoudloo, D. (2016). Evaluation of factors associated with failure of tuberculosis treatment under DOTS in northern Islamic Republic of Iran. Eastern Mediterranean Health Journal = La Revue de Sante de La Mediterranee Orientale $=$ Al-Majallah Al-Sihhiyah Li-Sharq Al-Mutawassit, 22(2), 87-94.

Sjattar, E. L., Nurrahmah, E., Bahar, B., \& Wahyuni, S. (2011). Pengaruh Penerapan Model Keluarga untuk Keluarga Terhadap Kemandirian Keluarga Merawat Penderita TB paru Peserta DOTS di Makassar (Integrasi Keperawatan Self Care dan FamilyCentred Nursing), 4674.

Sukoco, W. (2012). A Qualitative Study on Interaction Between Pulmonary Tuberculosis Patients and the Roles of Treatmen Observer (PMO) in Majalengka Distric, 339-344.

Syed, M. A. (2014). Treatment Outcome of Tuberculosis Patients Registered at DOTS Centre in a Tertiary Care Hospital. International Journal of Infectious Diseases, 21, 256. https://doi.org/10.1016/j.ijid.2014.03.95 3

Tjokroprawiro, A., Setiawan, B. P., Effendi, C., Santoso, D., \& Soegiarto, G. (2015). Buku Ajar Ilmu Penyakit Dalam (2nd ed.). Surabaya: Airlangga University Press (AUP).

World Health Organization. (2016). Framework of Indikators and Targets for Laboratory Strengthening under the End TB Strategy (Vol. 1). WHO Library Cataloguing. https://doi.org/978 9244 1511438

World Health Organization. (2017). Global Tuberculosis Report. Genewa, Swiss: Switzerland.

World Health Organization (WHO). (2016). 
Global Tuberkolosis report. (World

Health Organization (WHO), Ed.).

Switzerla: Library Cataloguing-in-

Publication Data. 